\title{
30 YEARS OF THE POLISH SOCIETY OF PHLEBOLOGY - HOW IT ALL HAPPENED
}

Tomasz Drążkiewicz

Department of Vascular Surgery and Endovascular Procedures, the John Paul II Hospital, Kraków, Poland

My motto

If you do something important and it survives, you should always be respected, happy and calm.

\author{
EDITORIAL PAPER \\ Phlebological Review 2021; 29, 1: 3-18 \\ DOI: https://doi.org/10.5114/pr.2021.106836 \\ Submitted: 30.04 .2021 \\ Accepted: 18.05.2021

ADDRESS FOR CORRESPONDENCE
Tomasz Drązkiewicz
Department of Vascular Surgery
and Endovascular Procedures
The John Paul II Hospital
80 Pradnicka St.
31-202 Kraków, Poland
e-mail: t.drazkiewicz@szpitaljp2.krakow.pl

THE FIRST MENTION OF VEINS IN THE HISTORY OF MEDICINE

\section{Ancient history}

\section{$4^{\text {th }} / 3^{\text {rd }}$ century B.C.}

Hippocrates (c. 460-c. 377 BC), Greek physician, one of the precursors of modern medicine (author of Corpus Hippocraticum), known as the father of medicine.

\section{$2^{\text {nd }}$ century A.D.}

Galen - Claudius Galenus (129-200 A.D.), Roman doctor of Greek origin, anatomist, philosopher, talented researcher, and writer, one of the most outstanding ancient doctors. He described, among other things, the heart valves and the differences between the arteries and veins. He established that blood flowed through the arteries and veins, not air, as previously thought.

\section{Modernity/renaissance}

\section{7}

Leonardo da Vinci (1452-1519), Italian Renaissance painter, sculptor, architect, engineer, explorer, mathematician, anatomist, inventor, geologist, philosopher, musician, writer. He deduced that all veins and arteries derive from the heart.

\section{8}

William Harvey (1578-1657), English biologist. He made a breakthrough in biology by describing the blood- stream. For the first time ever, he discovered that the heart acts as a suction pump and causes constant blood circulation in the vessels with which it forms a closed system.

\section{SELECTED ESSENTIAL INFORMATION ABOUT PHLEBOLOGY IN THE WORLD}

The history of varicose veins treatment goes back to ancient times. However, for many centuries no diagnostic methods were known, and the methods of treatment were very primitive and limited.

Contemporary phlebology was beginning to develop starting in the mid- $18^{\text {th }}$ (compression therapy) and early $20^{\text {th }}$ century. Some of the most famous pioneers of invasive phlebology treatment were W.W. Babcock ${ }^{1}$ (1907, Philadelphia, USA) and both J. Sicard (Paris, F) and P. Linser (Tübingen, D), who in 1904 simultaneously and accidentally discovered the possibility of sclerotherapy of varicose veins.

In the $20^{\text {th }}$ century, classic surgery and classic sclerotherapy were the main methods used in the invasive treatment of varicose veins of the lower extremities. Over the last decade of the $20^{\text {th }}$ century and the two decades of the $21^{\text {st }}$ century the diagnostics, prophylaxis and treatment of varicose veins have changed radically thanks to the use of constantly improved medical equipment including duplex Doppler ultrasound (DUS/USG) and radiological equipment with the use of innovative treatment techniques. Thanks to the improved classic surgery of varicose veins (limited stripping, phlebectomy) and dynamic development of minimally invasive endovascular/endovenous

\footnotetext{
${ }^{1}$ Babcock WW. A new operation of varicose veins of the leg.
} New York Medical J 1907; 86: 153-156. 
methods using inter alia radio, laser, steam ablation or chemical obliteration (adhesives, foam sclerotherapy), there is tremendous progress in terms of both safety and effectiveness.

\section{7}

It was not until 1947 that Raymond Tournay (18931984) coined the term phlébologie, and he introduced this term into the world's medical vocabulary and terminology.

The oldest scientific and didactic association in the field of phlebology is the French Society of Phlebology (Société Française de Phlébologie - SFP), founded in 1947 in Paris by R. Tournay, J. Sicard and J. Marmasse. R. Tournay was its general secretary for many years.

\section{3}

The second national association was the Phlebological Association of Italy (l'Associazione Flebologica d'Italia) now the Italian Society of Phlebology/Società Italiana di Flebologia (SIF). Their founder was G. Bassi. Currently, five separate associations with a phlebological profile originate from here.

\section{7}

The third national association was the German Society of Phlebology (Deutsche Gesellschaft für Phlebologie DGP), founded March 24, 1957 in Frankfurt/M initially as the Deutsche Arbeitsgemeinschaft für Phlebologie. Indeed there was an Association of Specialists for Leg Diseases in Germany between 1909 and 1934, even temporarily publishing its own journal, but with regard to current standards, this organization was more a professional association than a scientific society. Therefore, the majority of authors agree that the Société Française de Phlébologie (SFP) was the world's first scientific phlebological association. Here is a classic example of the importance of historical details in the competition for the palm of priority.

In the same year, on November 16, 1957, the fourth association, the Benelux Society of Phlebology (Benelux Vereniging voor Flebologie/Société Bénéluxienne de Phlébologie) was founded in Eindhoven under the aegis of H.R. van der Molen.

\section{9}

On March 24, 1959 in Paris, Union Internationale de Phlébologie (UIP ${ }^{2}$ /International Union of Phlebology (IUP) was established by these four previously existing associations. The first UIP World Congress was held in Chambéry in 1960. Directors: J. Marmasse and Suzanne

\footnotetext{
${ }^{2}$ www.uip-phlebology.org/history.
}

Bourgeois. The last one $\left(18^{\text {th }}\right)$ UIP World Congress took place in February 3-8, 2018 in Melbourne (Australia). The next $\left(19^{\text {th }}\right)$ UIP Congress should be in Istanbul, Turkey in September 12-16, 2022. Today UIP is composed of 74 member societies from 71 countries. The current UIP president is K. Parsi (Australia, 2019-2023). Former UIP president: N. Morrison (USA, 2015-2019).

\section{0}

The Swiss Society of Phlebology (SSP) was constituted by A. Bolliger, H.J. Leu and K. Sigg.

\section{3}

The Scandinavian Society for Phlebology/Societas Phlebologica Scandinavica (SPS) (Denmark, Finland, Norway and Sweden) was founded by G. Bauer and K. Hæger.

\section{8}

The first Latin-American purely phlebologically orientated association, the Sociedad Argentina de Flebologia $y$ Linfologia (SAFL), was brought to life and was acknowledged by the bodies of the UIP.

\section{3}

The Canadian Society of Phlebology (Société Canadienne de Phlébologie - SCP) was founded by G. Cloutier.

\section{4}

The Australasian College of Phlebology (ACP): In 1999 the name was officially changed to the present one when connection was made from originally the Australian and New Zealand Society of Phlebology, founded by P. Conrad and W. Campbell (1974) and the Sclerotherapy Society of Australia, founded by P. Thibault (1993). ACP is currently the most advanced in the world in phlebology education. There are a number of different membership (fellowship) classes to incorporate a variety of professionals working in areas related to phlebology.

Currently, there is no formal recognition for phlebology as a medical specialty in the world. In Australia, ultimately, the long term goal of ACP is achieving Australian Medical Council (AMC) recognition of phlebology as a distinct medical specialty. The recognition process is a long one and needs a lot of resources. The ACP is committed to achieving this aim.

\section{5}

Especially interesting is the history of the establishment of the phlebology society in the USA. It all started with A. Butie (originally from Switzerland), who found- 
ed the North American Society of Phlebology (NASP) in August 4, 1985, incorporated the society in June of 1986, and held the first annual meeting in February of 1988. At that time in the United States the use of Doppler ultrasound (DUS/USG) was not widely known and not used for evaluation of varicose veins. Doctor Butie's vision was to share his knowledge to improve patient care in the USA. There was a group in New York that already had some sort of a society founded, but he was not impressed with the level of scientific knowledge in that group, so he decided to start own group together with 14 co-founder members. Based on the NASP, different branches were formed and are now functioning, working together with different associations. The most famous of these are: the American Venous Forum (AVF) founded in 1987, and the American College of Phlebology (ACP), which today is called the American Vein and Lymphatic Society (AVLS) - the name was changed on November 19, 2018 during the $32^{\text {nd }}$ ACP Annual Congress in Nashville, Tennessee, USA. Regardless of their goals and form and mode of action, all these organizations identify Dr Butie as the founder of American phlebology.

\section{1}

The Polish Society of Phlebology (PTF), initially as the Society of Phlebology in Katowice, was founded on September 23, 1991 on the initiative of T. Drążkiewicz on June 23, 1991. The PTF is the first medical association founded in Central and Eastern Europe after 1989 $9^{3}$. A year later, the second such society was established in the Czech Republic.

\section{2}

Czech Society of Phlebology/Česka Flebologicka Společnost (CFS). The founder (1992) of the CFS, Maruška Horáková (1925-2003), was one of the most famous, outstanding phlebologists, sitting in the authorities of the UIP and honoured with honorary membership of several phlebology societies. Earlier (1973) the Phlebology Section of the Czech Society of Dermatology and Venereology was established.

\section{0}

The European Venous Forum (EVF) was established in 2000 in Lyon, France as an idea of A. Nicolaides under the leadership of M. Perrin. The EVF works under the auspices of the Union Internationale de Phlébologie (UIP) and the International Union of Angiology (IUA). The objective is to develop education, scientific knowledge, research and clinical expertise of the highest quality and establish

\footnotetext{
${ }^{3}$ June 4, 1989 - the first free elections and the end of real socialism in Poland.
}

standards in the field of venous disease. Membership is wide and open to anyone who has an interest in the field irrespective of medical discipline. The EVF was founded to follow the example of the American Venous Forum (AVF, founded 1987), according to Bo Eklöf, a former president of the AVF. M. Perrin confirmed this, stating: "the AVF was the stimulus for the creation of the EVF." Perrin added - laughing, as he looked back at that first Lyon Congress - "I did not care about an article published in a French vascular journal some months later, which stated that 'Michel Perrin is a traitor, because he organised an English-speaking convention in Lyon, the Gaul capital"' This is just one example in this foreign place of how difficult it is to convince some of a new idea (author's - T.D., footnote).

\section{0}

The first European Venous Forum Hands-on Workshop on Venous Disease (EVF HOW) was organized in 2010 in Larnaca, Cyprus. Chairmen: B. Eklöf and P. Neglén.

\section{3}

European College of Phlebology (ECoP). Why was the ECoP founded?

E. Rabe, ECoP founder: "Venous disease is common in Europe. The development of phlebology in the last decade has changed the medical profession substantially. Nevertheless, phlebology is not well recognized in the European medical system. In addition, phlebology is an interdisciplinary specialisation involving vascular surgeons, internists, dermatologists, radiologists, haematologists, general practitioners and practitioners of other disciplines who also play an important role in patient care. To endorse the European cooperation in phlebology, including education and certification, we founded the European College of Phlebology in April 2013".

The founding executive board of the ECoP, E. Rabe, M. Neumann, A. Davies and C. Wittens, would like to invite you to the first ECoP Course to be held 26-28 of November 2021 in Amsterdam. This course is organized with educational lectures and hands-on practical training especially for the professionals dedicated to venous disease.

All professionals - nurses, vascular technicians, doctors, medical specialists, trainees and all others involved in venous pathology - are invited to join in. The European College of Phlebology supports Phlebology in Europe.

\section{5}

The EVF HOW Plus - new improved practical courses. Started in an improved form in 2015 by O. Maleti and Marzia Lugli. Originator: Bo Eklöf. 


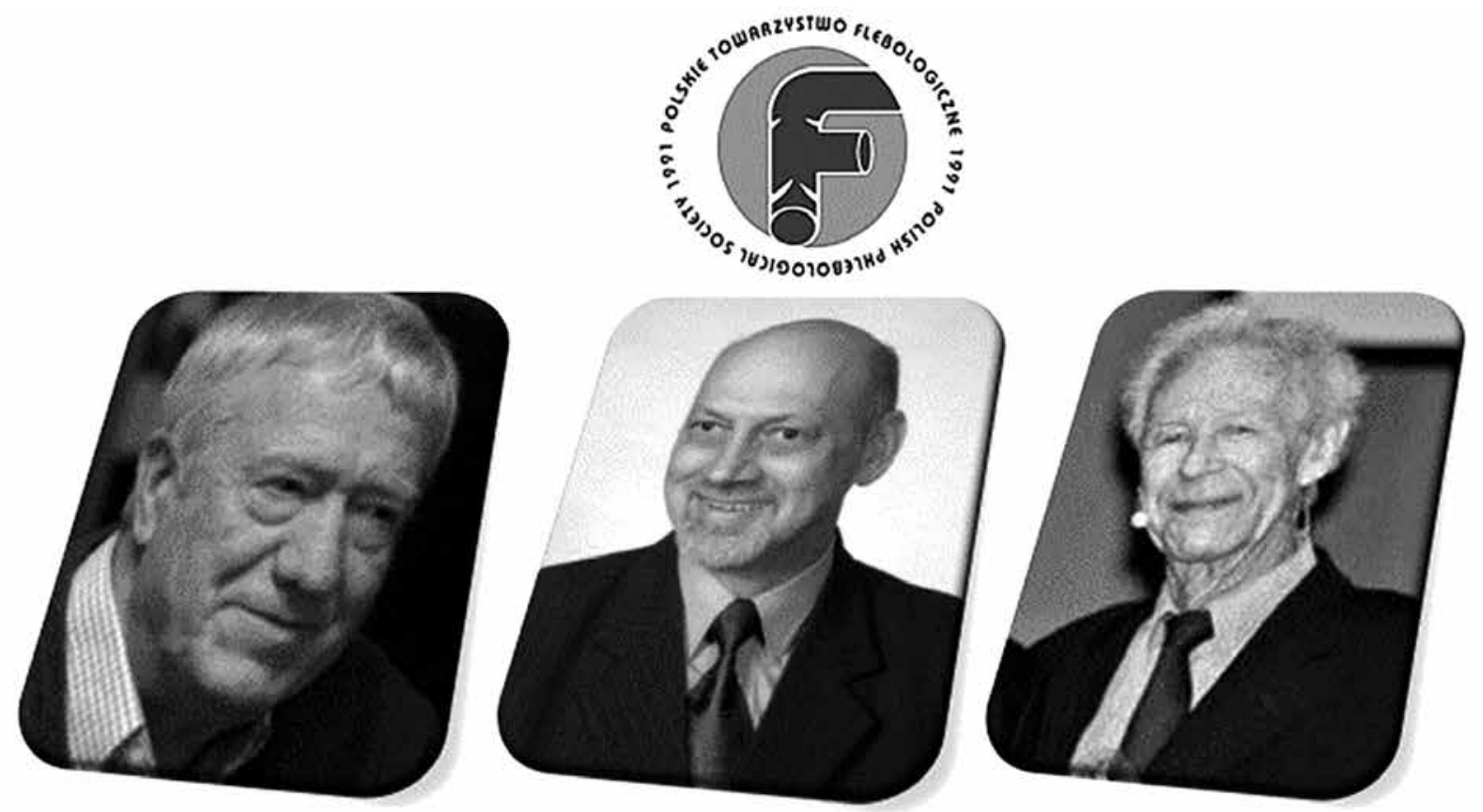

Fig. 1. Fathers of the idea of establishing a phlebological association in Poland, from left to right: B. Eklöf (S), T. Drążkiewicz (PL), W. Hach (D)

\section{THE POLISH SOCIETY OF PHLEBOLOGY (POLSKIE TOWARZYSTWO FLEBOLOGICZNE - PTF)}

The history of the society is based on my memory, but also on the memory of the witnesses of those events, as well as the preserved archival evidence-based documents. Special thanks go to Mrs. Ewa Skwarek, who for 10 years - from 1992 to 2002 - was leading the PTF Authorities Office and the Editorial Office of the Phlebological Review.

I have been asked many times about how the PTF was established. Let everything be clear: from the autumn of 1990, my intention was to establish a nationwide association of phlebology in Poland.

My idea of establishing the society was surprising. Here we must go back to the end of the 1980s and the beginning of the 1990s. Back then, I could not have foreseen how my two casual contacts with B. Eklö ${ }^{4}$ and W. Hach ${ }^{5}$ would have such a significant impact on my personal and professional future, and not only mine (Fig. 1).

\section{The beginnings of modern phlebology in Poland}

In Poland, the medical community has been interested in and dealt with venous issues for many generations. At this point, it is impossible to mention even the most important

${ }^{4}$ Professor Bo Eklöf (b. 1935), MD, PhD - Swedish general and vascular surgeon, phlebologist. President of the American Venous Forum (2003-2005) and the American Venous Forum Foundation (2007-2008).

${ }^{5}$ Professor Wolfgang Hach (b. 1930), MD, PhD - German general and vascular surgeon, internist, radiologist, phlebologist. First Honorary Member of the Polish Society of Phlebology (1994). ones in this topic. At the beginning of the twentieth century, as soon as W.W. Babcock developed (1905) and published (1907) the original method of varicose vein surgery, such operations began to be performed around the world, including in Poland in all hospitals with surgery departments within their structures. As I mentioned above, in 1947 in France, R. Tournay introduced the term phlebology to the medical vocabulary, which was slowly spreading in other countries. Until 1990, there were many famous doctors in Poland, mainly surgeons treating venous diseases, but no one used the term phlebology. It should be noted here that at the end of the 1980s, in the so-called Eastern European Countries, including Poland, mostly matters in medicine were determined not only by professional but also political considerations. At that time in Poland, it was not customary to use Western neologisms in medicine. I came across this term for the first time in 1988, when - while working as a surgeon in Kuwait, I met Professor Bo Eklöf from Sweden, who said that he was working in Kuwait as a vascular surgeon, phlebologist, and the head of the University Department of Vascular Surgery. He added that perhaps we would be able to establish cooperation when I completed the Polish contract as general surgeon. I did not ask what exactly he meant then, but I really liked the topic of phlebology very much. However, cooperation did not take place, because immediately after this meeting, I found out that in October 1988, Professor Roman Adamczyk ${ }^{6}$ - the head of the

${ }^{6}$ Professor Roman Adamczyk (1925-1988), MD, PhD - one of the pioneers of general, vascular, cardiac surgery and phlebology in Poland - head of the Department of General and Vascular Surgery (1977-1988), University of Silesia, Katowice, Poland. 
department where I worked in Katowice since 1977 - died suddenly. So I decided to return to Poland to continue my work in the department and further research and teaching activities. Several years later, the very friendly cooperation of our society with B. Eklöf began, and it continues to this day.

One and a half years later in August 1990, during a holiday trip to the south of Europe, I stopped for a week in the health resort of Bad Nauheim, near Frankfurt am Main. I fortuitously found out that there is a hospital where, among other things, varicose veins are treated. I decided to go there. It turned out to be William Harvey Klinik, which still operates, among others, the Vascular Surgery Department. It was then that I got to know the medical director and the head of the department. He was Professor Wolfgang Hach, widely known in Europe and around the world. When he found out where I was from and what I was doing, he invited me to the hospital for a few days as a visiting vascular surgeon. On the very first day, I heard again the word 'phlebology'. I learned that Professor Hach was an active long-term member and current president (1988-1991) of the German Society of Phlebology (DGP), which had been in existence for 33 years at the time. During that meeting the question was - among other things - whether there was any phlebological association in Poland. If so, the DGP would be open to cooperation with Polish phlebologists. I replied that I did not know because I had been working abroad for almost two years, but after returning from vacation I would check and let him know. At the end of this meeting, I also learned that in the autumn of 1991 another $34^{\text {th }}$ Congress of this Society (DGP) would be held in Frankfurt am Main, to which I was initially invited. I left there convinced that probably such an association or at least some phlebology section existed in Poland. After returning to Poland in September 1990, I paid a visit to the Provincial Court in Katowice. After a few days, it turned out that no medical association with such a profile was registered in Poland! The second piece of good news was that thanks to the first free elections held in Poland 15 months earlier - on June 4, 1989 - and the end of real socialism in Poland, many regulations had been changed, among others, those related to the registration of associations. Before that, registration with the Supreme Court was required. Now such registration could take place in the Provincial Court, in accordance with the place of the planned seat of the association! I received instructions with a list of the necessary documents to be submitted. These were: application for the registration of the association, a list with the signatures of at least 15 co-founder members, and the statute.

I let Professor Hach know, and soon he sent me not only the current DGP statute, but also the statutes of several other phlebological societies to which he had access. When, after a few months, I had developed the draft statute, I met two people who had been treating vein diseases in their private centre in Zabrze since 1985. They were Dr Krystyna Twardowska-Saucha and her husband, a law- yer, Bogusław Saucha. This cooperation was very beneficial for many years to come. In the spring of 1991, thanks to the very significant help of B. Saucha, as an outstanding lawyer, we jointly proceeded to refine the final version of the statute. The task turned out to be much more difficult and complex than it seemed at the beginning. At that time, I did not realize how much work and effort I had to do. The question arose: Why are 15 people required to register? It turned out that this was the number necessary to conduct the founding meeting and appoint the so-called officials to the authorities, and then to register the association.

\section{Beginnings of the Polish Society of Phlebology}

1991.06.23, Katowice (Poland) - initial meeting with the participation of T. Drążkiewicz, originator and initiator of the establishment of the Polish Society of Phlebology, author of the draft statute and B. Saucha, co-author of the draft version of the statute. The main purpose of this meeting was to prepare the documents necessary to convene the founding assembly. Here I would like to announce that after this meeting I sent invitations to 52 heads of clinics and departments of the Silesian Medical Academy in Katowice ${ }^{7}$, to participate in the founding meeting. After three months, only three had replied.

1991.09.23, Katowice (Poland) - the founding meeting. A broader explanation should be given at this point. Well, from the very beginning, my intention was to establish a nationwide association called the Polish Society of Phlebology. What, then, was the real reason for the original name: Society of Phlebology (without the word 'Polish')? According to the archival protocol from the founding meeting (September 23, 1991), in the draft statute submitted at that time, together with Mr. Saucha, we entered the name PTF. Unfortunately, three candidates for the future Scientific Committee, who were present at the founding assembly - raised a reservation, questioning this name. They proposed the name 'Society of Phlebology in Katowice. They argued that the name of the PTF proposed by both of us could cause an unpredictable reaction from the medical community in Poland, especially among vascular surgeons. In this situation, we both (Mr. Saucha and I) submitted a motion to put this topic to a vote. Unfortunately, the vote did not take place in the end. I think that at this meeting no one, except the two of us, fully believed in the success of the entire project. So, the name of the Society of Phlebology in Katowice remained, but I managed to push through the entry in $\$ 1$ of the statute: "The area of the Society's activity is the territory of the Republic of Poland." Opponents sceptical about the name PTF were partially right. When the news of the new movement spread throughout Poland, there was an embarrassing silence on the side of vascular surgeons that lasted almost a year, which meant that this information was not accepted. The situation improved

\footnotetext{
${ }^{7}$ Now the Medical University of Silesia in Katowice, Poland.
} 
when I started explaining to sceptics that our society was multidisciplinary, and hence our members included both doctors of various specialties and people representing other professions (e.g., nursing, rehabilitation, physiotherapy, and many others, even law), which meant that our activities, from the very beginning, would not interfere with the activities of other associations. In mid 1992, there was a breakthrough change of attitude - among others, on the part of the most influential vascular surgeons at the time, who had just established the Polish French Angiological Society (P-FTA) on the initiative of Z. Mackiewicz (Poland) and M. Perrin (France). During the $1^{\text {st }}$ P-FTA Congress, which was then held in Puktusk (Poland), it was finally acknowledged and confirmed that we had a nationwide phlebological society, which was established as the first medical association in Poland and in our part of Europe after 1989. From that moment on, other medical associations of various profiles began to emerge, including the Polish Angiological Society (PTA) (B. Kowal-Gierczak, Wrocław, 1992). I think that the above statements comprehensively answer important questions about the origins of our society.

The participants were the following persons (in alphabetical order), who were specified in the protocol as co-founder members: Marek Błaszczyński (Katowice), Marek Drążkiewicz (Bielsko-Biała), Tomasz Drążkiewicz (Katowice), Urszula Drążkiewicz (Katowice), Zygmunt Fiutek (Zabrze), Jacek Gawrychowski (Zabrze), Teresa Kozik (Bielsko-Biała), Tomasz Kozik (Bielsko-Biała), Hanna Matuszewska-Zbrońska (Zabrze), Marian Pardela (Zabrze), Tadeusz Petelenz (Katowice), Bogusław Saucha (Zabrze), Krystyna Twardowska-Saucha (Zabrze), Ryszard Zbroński (Zabrze), Krzysztof Ziaja (Katowice).

At this point it is worth adding that in June 1991, upon the news that I was going to organize a founding meeting in September with the participation of 15 people, I was informed by W. Hach that the Board of the German Society of Phlebology (DGP) had decided on his request to invite all 15 co-founder members of our society to participate in the $34^{\text {th }}$ DGP Congress, which was to take place in early October. We had very little time, but we made it. Two weeks after our meeting, we travelled with a group of 14 out of 15 co-founder members to Frankfurt am Main. Those were four unforgettable days. We all received free congress participation and a free 4-day stay in top-class hotels and a staggering amount of DM 500 per person for our own needs! It should be remembered that at that time the monthly salary of a doctor in Poland was the equivalent of no more than $50 \mathrm{DM}($ !). Since then, there has been very close and successful cooperation with DGP. Thanks to this, many Polish phlebologists have trained in local centres, as well as in other countries. For many years now prominent phlebologists from all over the world have accepted invitations to international meetings organized by us and often we hear from them that the level of phlebology in Poland is currently very similar to the global one. This is evidenced, for example, by the European Chapter Meeting of the International Union of Phlebology (UIP), organized in Kraków by the current president of the PTF (see below, under the date 2019.08.25-27).

1991.11.19, Katowice (Poland) - incorporation in the Court.

1991.11.27, Katowice (Poland) - $1^{\text {st }}$ General Assembly of Members. Election of the authorities for the $1^{\text {st }}$ term of office 1991-1994. President - T. Drążkiewicz (Katowice), Vice President - K. Twardowska-Saucha, General Secretary - B. Saucha, Treasurer - M. Błaszczyński, President Elect at the $1^{\text {st }}$ Congress of the Society (1994, Bielsko-Biała) - M. Drążkiewicz. Scientific Committee: M. Pardela, T. Petelenz, K. Ziaja.

1991.12.19, Katowice (Poland) - Acquisition of personality in law. This meant that our society could formally start operating in Poland and internationally.

1992.03.12, Warszawa (Poland) - Scientific Symposium (the first fully phlebological meeting in Poland). Post-thrombotic syndrome. Leg ulcers. Chairman: M. Szostek.

1992.05.18, Katowice (Poland) - $1^{\text {st }}$ Inaugural International Scientific and Training Conference of the Society (PTF). Phlebology Yesterday and Today. Chairman: T. Drążkiewicz. Special guest U. Schultz-Ehrenburg (D). Number of participants: 40.

1992.06.24, Katowice (Poland) $-1^{\text {st }}$ PTF Training Course. Sclerotherapy. Chairman: T. Drążkiewicz, M. Nowakowski.

1992.11.25, Katowice (Poland) $-2^{\text {nd }}$ Extraordinary General Assembly of Members. Change in the statute: change of the name from the Society of Phlebology to the Polish Society of Phlebology. The written application was submitted by Dr A. Witek, gynaecologist and obstetrician from Katowice, who later (1993) also became one of the editorial secretaries of the Phlebological Review. A similar oral proposal was made by colleagues from Wrocław: P. Szyber and Z. Rybak, very active organizers of many PTF meetings (see further information) (Fig. 2).

The Provincial Court in Katowice made an entry in the register of associations: Based on the documents provided (including the Protocol from the Extraordinary General Meeting of Members of November 25, 1992), the name was changed in the register of the nationwide association existing since September 23, 1991, from the Phlebological Society in Katowice, to the Polish Society of Phlebology. Thus, from a formal point of view, September 23, 1991 was recognized in law as the date of establishment of the Polish Society of Phlebology.

1992.11.25, Katowice (Poland) $-2^{\text {nd }}$ PTF Training Course. Phlebotropic drugs.

1993.04.23, Katowice (Poland) $-3^{\text {rd }}$ PTF Training Course. Practical Aspects of Compression Therapy and Sclerotherapy.

1993.05.21, Katowice (Poland) - meeting of the PTF Main Board. An official journal of the PTF was established, as well as the bilingual Polish-English journal Phlebological Review. At that time, it was - after the British Phlebology - the world's second English-language journal of phlebo- 


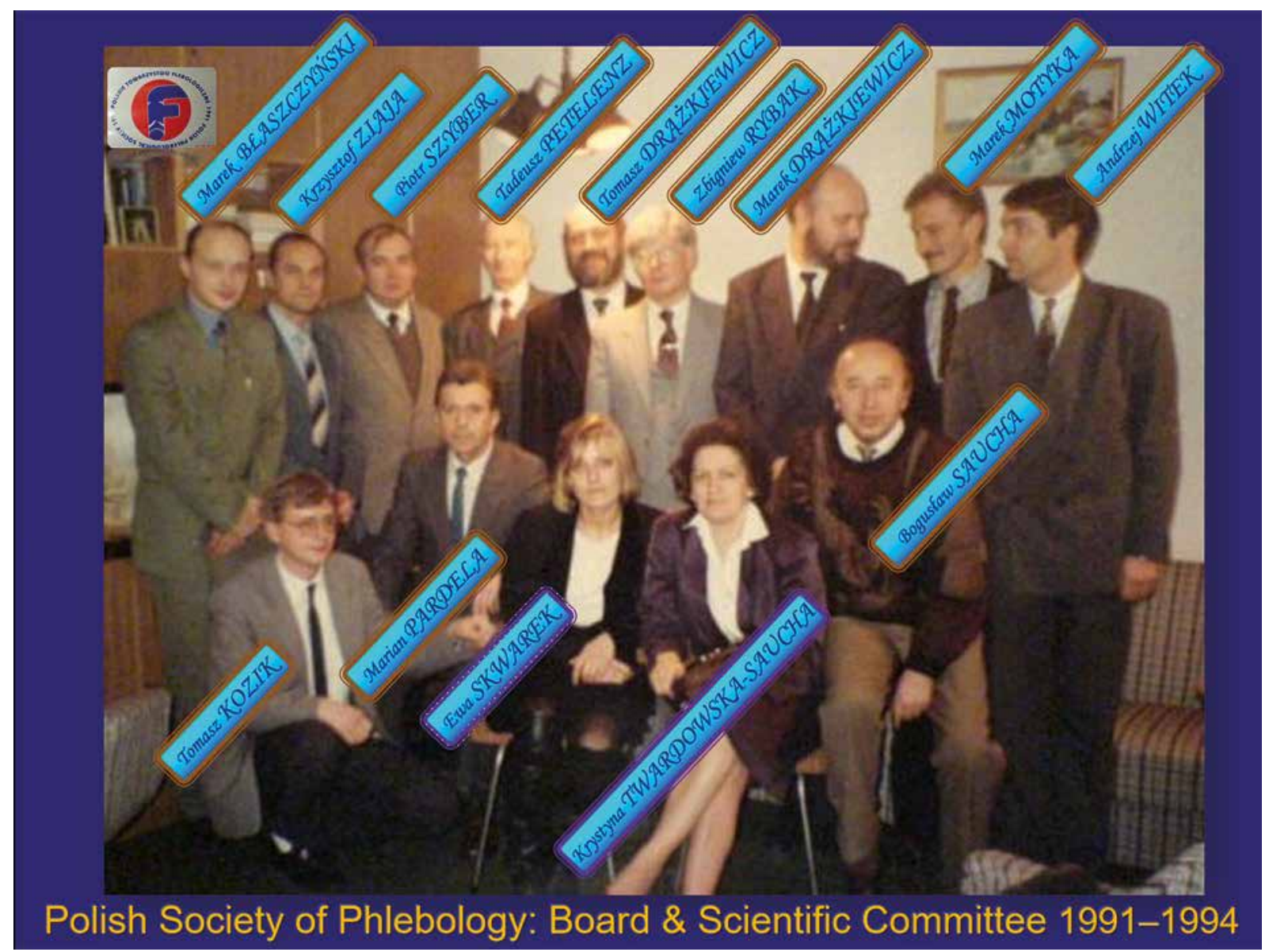

Fig. 2. Polish Society of Phlebology, 25.11.1992, Katowice (PL). Management: Board and Scientific Committee (1991-1994)

logy. Being the initiator and founder of this journal, I was elected Editor-in-Chief by the PTF Board (1993-2001, volume 1-9). The subsequent Editors-in-Chief were: M. Skórski (2002, volume 10) and Z. Rybak (2003-2013, volume 11-21). Currently (from 2014, volume 22) the Editor-inChief is M. Simka. Currently, the journal is published in English under the name Phlebological Review. In 2022, we will celebrate the $30^{\text {th }}$ year (volume 30 ) of publishing our journal. So, there will be an opportunity to summarize and present the next chapter in the history of Polish phlebology.

1993.06.05, Katowice (Poland) $-2^{\text {nd }}$ PTF International Scientific and Training Conference. Practical Aspects of Compression Therapy and Sclerotherapy. Chairmen: $\mathrm{T}$. Drążkiewicz, M. Nowakowski. Number of participants: 110.

1993.09.06-10, Budapest (Hungary) - $1^{\text {st }}$ European Congress of the Union Internationale de Phlébologiel International Union of Phlebology with around 1000 participants from all over the world, including a large group of Polish phlebologists. At the congress, which took place simultaneously with the $56^{\text {th }}$ Congress of the Society of Polish Surgeons (see below), about 1000 participants attended.

1993.09.06-10, Lublin (Poland) $-56^{\text {th }}$ Congress of the Society of Polish Surgeons (Towarzystwo Chirurgów
Polskich - TChP). The chairman, P. Misiuna ${ }^{8}$, wanting to honour the establishment of the Polish Society of Phlebology (1991), planned the first Phlebology Session in Poland during the TChP Congress, inviting me to conduct it. Unfortunately, this session was cancelled because the leader of the previous session, Prof. Andrzej Cencora ${ }^{9}$, suddenly fainted - he happily recovered soon, and this event went down in history both in Polish surgery and phlebology.

1993.12.07, Katowice (Poland) - Inaugural edition of the bilingual (Polish and English) official indexed journal

\footnotetext{
${ }^{8}$ On January 8, 2021, the sad news reached us - Professor Paweł Misiuna (1928-2021) died at the age of 93. He was $\mathrm{MD}, \mathrm{PhD}$, an outstanding general surgeon, vascular surgeon, oncologist and phlebologist, founder, and head of the Vascular and then General Surgery Departments in Lublin, Provincial (Lublin) and regional consultant, academic teacher, and tutor of several generations of doctors. We honor his memory.

${ }^{9}$ Professor Andrzej Cencora (1938-2008) - general and vascular surgeon, angiologist, phlebologist. Provincial (Kraków) and Regional Consultant for vascular surgery. Head of the Department of Vascular Surgery and Angiology (1982-2006). University teacher. Polish representative in the European Society of Vascular Surgery.
} 


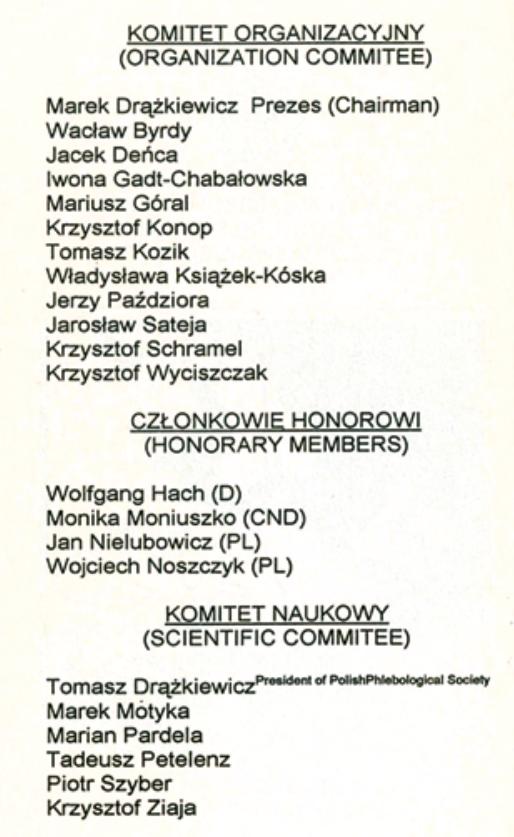

TEMATYKA KONGRESU (MAIN TOPICS)

Zakrzepica żylna (Venous thrombosis) Dostęp żylny do dializ. (A-V fistulas for hemodialysis)

Nowości flebologiczne (What's new in

phlebology?)

PROGRAM (GENERAL PROGRAMME)

29. IV. 94 .

$11^{\circ 0}$ Otwarcie obrad (Opening ceremony)

$11^{15}-18^{\circ}$ Sesje naukowe (Scientific sessions)

$19^{\circ 0}$ (7 PM) Spotkanie uczestników, koktail

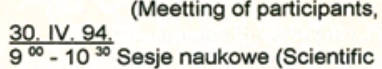

sessions)

$11^{\infty}-12^{\infty}$ Walne zebranie członków PTF

$13^{\infty}-14^{\infty}$ (Meeting of members PTF) sessions)

Udział w Kongresie prosimy zgłaszać przed

Please submit Your participation before $1^{\text {tht }}$ of November 1993

Koszty będa przedstawione w komunikacie końcowym. (Costs will be presented in the final announcement).

Wystawy sprzetu medycznego odbęda się jednocześnie z Kongresem. (Trade exhibition will be held in conjuction with the Congress).

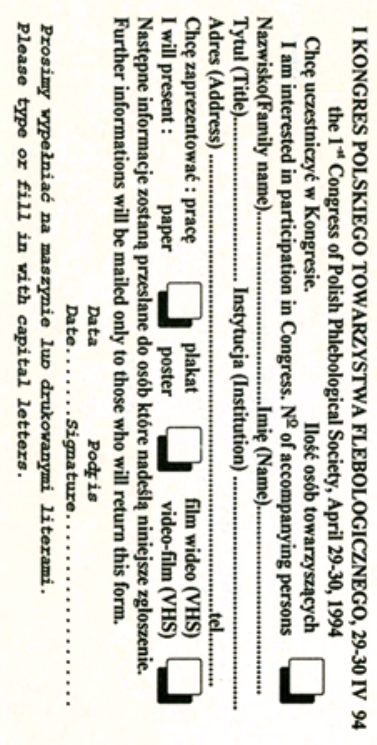

\section{$1^{\text {st }}$ Congress of the Society - April 29-30, 1994 / Bielsko-Biała}

Fig. 3. $1^{\text {st }}$ Congress of the Polish Society of Phlebology, 1994, Bielsko-Biała (PL) - information

of the Polish Society of Phlebology, Phlebological Review 1993; 1: 1-87.

1994.04.29-30, Bielsko-Biała (Poland) - $1^{\text {st }}$ Inaugural International Congress of the Polish Society of Phlebology. President of the Congress: M. Drążkiewicz. (Fig. 3). Number of participants: 375 .

Special Lecturers: W. Hach (D), G. Fegan (UK), U. Hepp (D), M. Moniuszko (CA), W. Noszczyk (PL), Z. Várady (D), J. Grotewohl (D), A. Cavezzi (I). During the congress, 6 phlebologists received a diploma of Honorary Member of the Polish Society of Phlebology: W. Hach, G. Fegan, M. Moniuszko, J. Nielubowicz, W. Noszczyk, Z. Várady.

1994.06.30 - $3^{\text {rd }}$ General Assembly of PTF Members. Election of the authorities for the $2^{\text {nd }}$ term of office 19941997.

President - T. Drążkiewicz (Katowice), Vice President - K. Twardowska-Saucha, General Secretary - B. Saucha, Treasurer - M. Błaszczyński. President-Elect at the $2^{\text {nd }}$ Congress of the Society (1997, Wrocław) - P. Szyber. Scientific Committee: M. Pardela, T. Petelenz, K. Ziaja.

1994.05.10, Zabrze (Poland) - $1^{\text {st }}$ PTF International Sclerotherapy Training Course. Training Course Manager: G. Fegan, Chairmen: Krystyna Twardowska-Saucha, T. Drążkiewicz. (Fig. 4).

1995.09.03-08, London (United Kingdom) $-12^{\text {th }}$ World Congress of the International Union of Phlebology (UIP/IUP). Primary handing over of the application for the admission of PTF to UIP: T. Drążkiewicz (PTF president) to G. Jantet (UIP president).

1995.04.26, Katowice (Poland) $-3^{\text {rd }}$ PTF International Scientific and Training Conference. Ulcus Cruris.

1996.04.24-25, Katowice (Poland), Silesian Opera $4^{\text {th }}$ PTF International Scientific and Training Conference. $5^{\text {th }}$ Anniversary of the PTF. Compression Therapy - the first international trilingual meeting in Poland with simultaneous translation (Polish, English, German). Chairmen: T. Drążkiewicz, K. Ziaja. Number of participants: 350.

1997.04.27-29, Wroclaw (Poland) $-2^{\text {nd }}$ International Congress of the Polish Society of Phlebology. President of the Congress: P. Szyber. Special Lecturers (inter alia): W. Hach (D), A. Cavezzi (I), M. Perrin (F).

1997.04.29. - General Assembly of Members. Election of the authorities for the $3^{\text {rd }}$ term of office PTF 1997-2000.

President - M. Maruszyński (Warszawa), Vice President - Z. Rybak, General Secretary - Krystyna Twardowska-Saucha, Treasurer - M. Błaszczyński. Members of the Board: T. Drążkiewicz, M. Kucharzewski, S. Molski, A. Ruciński, A. Żychliński.

1997.09.12-13, Kołobrzeg (Poland) $-5^{\text {th }}$ PTF Jubilee International Scientific and Training Conference. Practical Course of Sclerotherapy (with live video recording). Chairmen: A. Żychliński, T. Drążkiewicz, M. Nowakowski. 


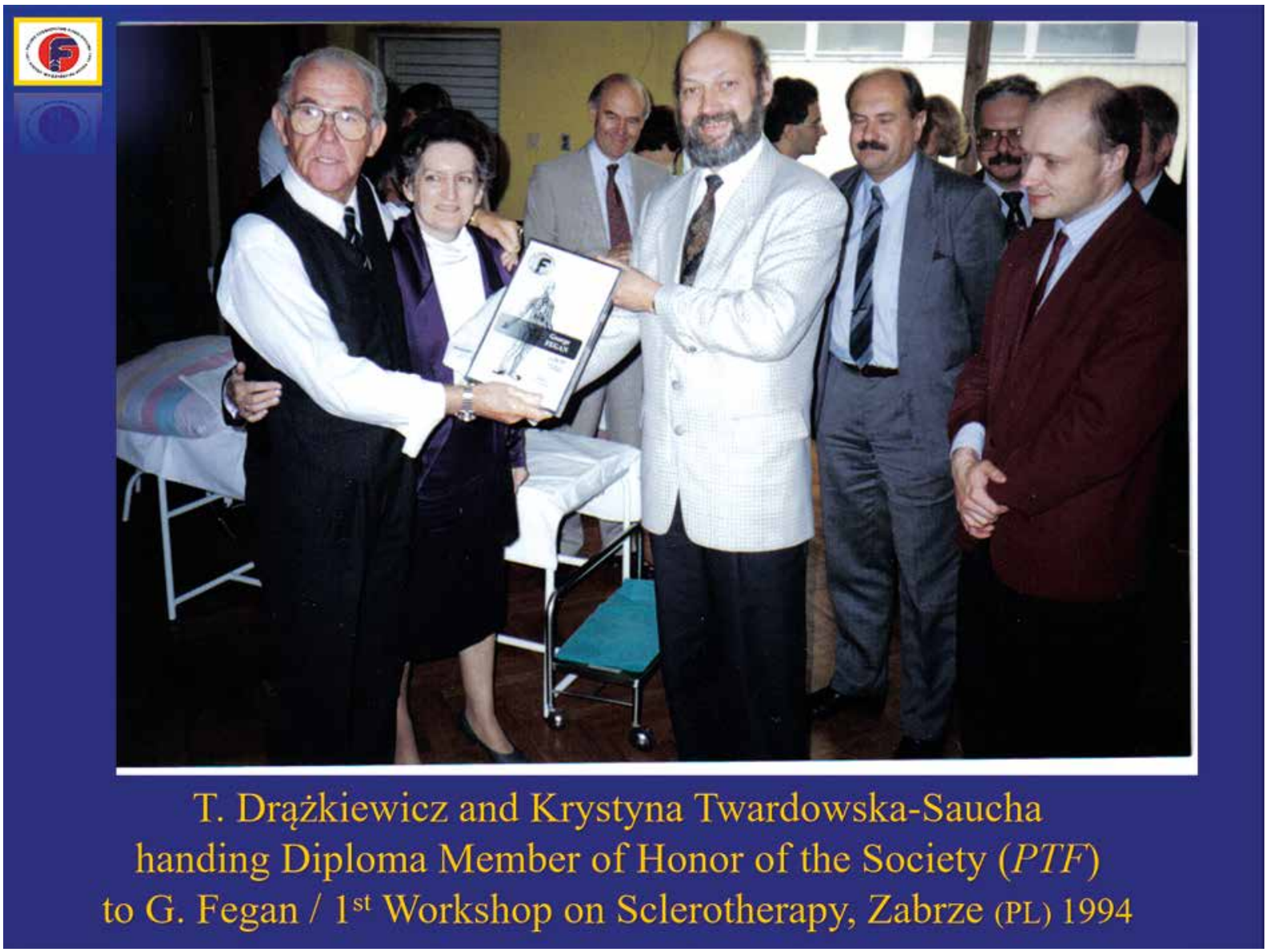

Fig. 4. ${ }^{\text {st }}$ Polish Society of Phlebology International Workshop for Sclerotherapy, 1994, Zabrze (PL). From left to right: G. Fegan (UK), Krystyna Twardowska-Saucha (PL), T. Drążkiewicz (PL), M. Błaszczyński (PL)

1998.03.12-14, Szklarska Poręba (Poland) $-6^{\text {th }}$ PTF International Scientific and Training Conference. Diagnostics of Vein Diseases (with live video recording). Chairmen: P. Szyber, Z. Rybak.

1998.06.17. - Affiliation of the PTF at the Polish Ministry of Health and Social Care.

1998.09.09-13, Sydney (Australia) - $13^{\text {th }}$ World Congress of the International Union of Phlebology (UIP). Important Event (1998.09.10): UIP Membership for the Polish Society of Phlebology - thanks to the Board of the UIP, especially: A. Davy (president of UIP 1989-1995), G. Jantett (president of UIP 1995-1999) and A. Nicolaides (former president of IUA). Documents for the access to UIP were prepared by: M. Maruszyński (president PTF, 1997-2000), T. Drążkiewicz (president founder of PTF, 1991) and Krystyna Twardowska-Saucha (general secretary of PTF, 1997-2000).

1999.03.11-14, Szklarska Poreba (Poland) $-7^{\text {th }}$ PTF International Scientific and Training Conference. Compression Therapy.

1999.05, Bydgoszcz (Poland) - $1^{\text {st }}$ Polish-Italian Phlebology Meeting.

1999.06.10-12, Berlin (Germany) - $1^{\text {st }}$ German-Polish Symposium of Phlebology.
2000.03.02-05, Szklarska Poręba (Poland) $-8^{\text {th }}$ PTF International Scientific and Training Conference. Venous Insufficiency and its Complications in Pregnant Women.

2000.05.23-25, Warszawa (Poland) $-3^{\text {rd }}$ International Congress of the Polish Society of Phlebology. President of the Congress: M. Maruszyński. Granting the title of honorary member of the PTF to special lecturer G. Jantett (F).

2000.05.25. General Assembly of PTF Members. Election of the authorities for the $4^{\text {th }}$ term of office 2000-2003.

President - Z. Rybak (Wrocław), Vice President M. Skórski, General Secretary - K. Twardowska-Saucha, Treasurer - A. Żychliński.

2001.03.01-04, Szklarska Poręba (Poland) $-9^{\text {th }}$ PTF International Scientific and Training Conference. $10^{\text {th }}$ Anniversary of the PTF. Laboratory Diagnostics Methods Used in CVI. Chairmen: Z. Rybak, P. Szyber.

2001.05.05, Bydgoszcz (Poland) $-10^{\text {th }}$ PTF International Scientific and Training Conference $/ 2^{\text {nd }}$ Polish-Italian Phlebology Meeting. Under the patronage of PTF (PL) and SIF (I).

2001.05.18-20, Kołobrzeg (Poland) - $11^{\text {th }}$ PTF International Scientific and Training Conference. Application of Freezing and Obliteration Techniques in the Treatment of Varicose Veins. $10^{\text {th }}$ Anniv. of the PTF. 
2002.03.01-03, Szklarska Poręba (Poland) $-12^{\text {th }}$ PTF International Scientific and Training Conference. PostThrombotic Syndrome (PTS).

2002.09.17-18, Sopot (Poland) $-13^{\text {th }}$ PTF International Scientific and Training Conference. Advances in Phlebology.

2003.02.27.-03.02, Krynica (Poland) $-14^{\text {th }}$ PTF International Scientific and Training Conference. Ulcus Cruris Venosum.

2003.05, Bydgoszcz (Poland) $-15^{\text {th }}$ PTF International Scientific and Training Conference. $3^{\text {rd }}$ Polish-Italian Phlebology Meeting. Under the patronage of PTF (PL) and SIF (I).

2003.06.20-23, Wrockaw (Poland) $-4^{\text {th }}$ International Congress of the Polish Society of Phlebology. President of the Congress: Z. Rybak. Special Lecturers (inter alia): M. Perrin, A. Cavezzi (I).

2003.06.23. - General Assembly of PTF Members. Election of the authorities for the $5^{\text {th }}$ term of office 2003 2006.

President - A. Jawień (Bydgoszcz), Vice President A. Cencora, General Secretary - M. Ciecierski. Treasurer - A. Żychliński.

2004.03.04-07, Szklarska Poręba (Poland) $-16^{\text {th }}$ PTF International Scientific and Training Conference. Compression Therapy. Treatment of Chronic Wounds.
2004.06.25-27, Warszawa (Poland) $-5^{\text {th }}$ Jubilee Congress of the European Venous Forum (EVF). President of the Congress: A. Jawień. Number of participants: 350.

2005.03.03-06, Krynica (Poland) $-17^{\text {th }}$ PTF International Scientific and Training Conference. Contemporary Trends in Phlebology.

2005.06.10-11, Bydgoszcz (Poland) $-4^{\text {th }}$ Polish-Italian Phlebology Meeting. Under the patronage of PTF (PL) and SIF (I).

2006.03.09-12, Szklarska Poręba (Poland) $18^{\text {th }}$ PTF International Scientific and Training Conference. Venous and Lymphatic Insufficiency and VTE in Pregnant Women.

2006.04.27, Kraków (Poland) - $1^{\text {st }}$ Kraków International Workshops of Phlebology (KIWP). Advances in Phlebology 2006. Chairmen: T. Drążkiewicz, J. Sadowski.

2006.06.01-03, Bydgoszcz (Poland) $-5^{\text {th }}$ Jubilee International Congress and $15^{\text {th }}$ Anniversary of the Polish Society of Phlebology. President of the Congress: A. Jawień. (Fig. 5).

The Ceremonial Lectures were given by special guests from abroad: BB. Lee (USA), N. J. Caprini (USA), N. Labropoulos (USA), N. Morrison (USA), H. Partsch (Australia), M. Perrin (France), A. Cavezzi (Italy).

2006.06.03 - General Assembly of Members. Election of the authorities for the $6^{\text {th }}$ term of office PTF, 2006-2009.

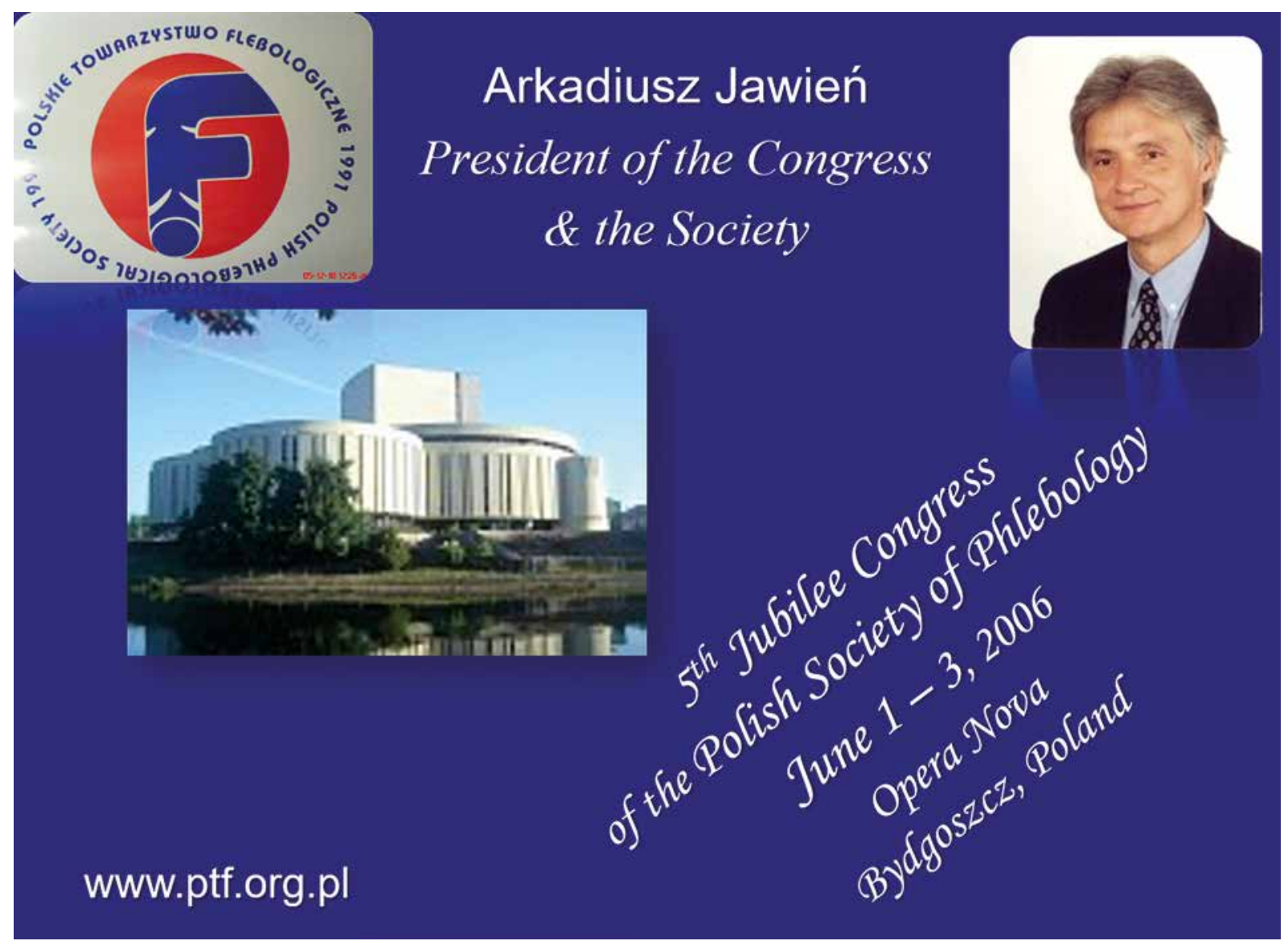

Fig. 5. $5^{\text {th }}$ Jubilee Congress and $15^{\text {th }}$ Anniversary of the Polish Society of Phlebology, 2006, Bydgoszcz (PL). Chairman: A. Jawien 
President - W. Staszkiewicz, Vice President - A. Cencora, General Secretary - G. Madycki. Treasurer - W. Hendiger.

2007.03.01-03, Szczyrk (Poland) $-19^{\text {th }}$ PTF International Scientific and Training Conference. Phlebology of the $21^{\text {st }}$ Century.

2007.04.19, Kraków (Poland) - $2^{\text {nd }}$ Kraków International Workshops of Phlebology (KIWP). Advances in Phlebology 2007 (more info, see: web).

2007.05, Bydgoszcz (Poland) $-5^{\text {th }}$ Jubilee Polish-Italian Phlebology Meeting.

2007.09.27, Mainz (Germany) - International Symposium of Phlebology: Hungary, Mexico and Poland. Phlebology Update. Chairman: Z. Várady.

2008.03.06-09, Szklarska Poręba (Poland) $-20^{\text {th }}$ PTF Jubilee International Scientific and Training Conference. Hemorrhoidal Disease and Aesthetic Phlebology. Chairmen: Z. Rybak, P. Szyber.

2008.05.08-09, Kraków (Poland) - $3^{\text {rd }}$ Kraków International Workshops of Phlebology (KIWP). Advances in Phlebology 2008.

2009.05.28-30, Warszawa (Poland) $-6^{\text {th }}$ International Congress of the Polish Society of Phlebology. President of the Congress: W. Staszkiewicz.

During the congress, in recognition of active organizational, scientific, and training activities, four persons were awarded honorary member of PTF diplomas. They were four presidents of previous PTF terms of office: T. Drążkiewicz, M. Maruszyński, Z. Rybak and A. Jawień. Diplomas were presented by W. Staszkiewicz, president of PTF (2006-2009).

2009.05.30. General Assembly of PTF Members. Election of the authorities for the $7^{\text {th }}$ term of office 2009-2012.

President - W. Staszkiewicz (Warszawa), Vice President - vacant, General Secretary - G. Madycki, Treasurer - W. Hendiger. Members of the Board: M. Gabriel, A. Jawień, G. Madycki, Z. Krasiński, P. Terlecki, Z. Rybak.

2010.03.11-14, Szklarska Poręba (Poland) - $21^{\text {st }}$ PTF International Scientific and Training Conference. Endovascular Treatment of Venous Diseases.

2010.06.10-11, Kraków (Poland) $-22^{\text {nd }}$ PTF International Scientific and Training Conference and $4^{\text {th }}$ Kraków International Workshops of Phlebology and Related Disciplines. Progress in Phlebology and Related Disciplines 2010. Advances in Phlebology, Angiology and Lymphology, CVI, Pulmonary Embolism, Leg Ulcers, Leg Lymphedema, Diabetic Foot. Live Op-Transmissions. Chairmen: T. Drążkiewicz, J. Sadowski.

A special event was the signing of the bestselling Polish edition of the book Chirurgia $\dot{Z} y \nmid$ (2010, volumes I, II) by the main author, Prof. Wolfgang Hach (original: VenenChirurgie ( $2^{\text {nd }}$ edition, 2007/D). Scientific consultation for the Polish edition of Prof. M. Szostek.

During the conference, the Board and the Scientific Committee of the PTF established a council which appointed the title (fellowship): Fellow of the Polish Soci- ety of Phlebology (FPSPh). This title was awarded to several distinguished Polish and foreign phlebologists ${ }^{10}$.

2011.03.10-13, Szklarska Poręba (Poland) $-23^{\text {rd }}$ PTF International Scientific and Training Conference. $20^{\text {th }}$ Anniversary of the PTF. Chairmen: Z. Rybak, P. Szyber.

2012.02.23, Kraków (Poland) $-24^{\text {th }}$ PTF Conference $/ 1^{\text {st }}$ Inaugural International Symposium on Venous Interventions. Acute and Chronic Deep vein Obstruction - Endovascular Treatment of Deep Vein Thrombosis and Chronic Obstruction of the Venous System. Initiator and chairman: T. Urbanek ${ }^{11}$.

2012.3.01-03, Zakopane (Poland) $-7^{\text {th }}$ International Congress of the Polish Society of Phlebology. President of the Congress: W. Staszkiewicz.

2012.03.01-03 - General Assembly of PTF Members. Election of the authorities for the $8^{\text {th }}$ term of office 2012-2015.

President - T. Urbanek (Katowice), Vice President W. Staszkiewicz, General Secretary - M. Kucharzewski, Treasurer - W. Hendiger.

2013.03.14-17, Szklarska Poręba (Poland) $-25^{\text {th }}$ PTF Jubilee International Scientific and Training Conference. Chairman: Z. Rybak.

2013.03.13-14, Kraków (Poland) $-26^{\text {th }}$ Conference $\mathrm{PTF} / 2^{\text {nd }}$ International Symposium on Venous Interventions. Focus on Compression.

2013.09.08-13, Boston (USA) - $17^{\text {th }}$ World Meeting of the International Union of Phlebology (UIP/IUP).

During this congress a Special Polish Session was held. Society Session: Polish Society of Phlebology, September 11, 2013, $9^{00}-10^{30}$ am. Chairman: T. Urbanek (details ${ }^{12}$ ).

2014.03.06-09, Karpacz (Poland) $-27^{\text {th }}$ International Scientific and Training Conference of PTF.

2014.09.12-14, Zakopane (Poland) $-28^{\text {th }}$ PTF Conference. Phlebology on the Kalatówki Glade ${ }^{13} / v .1 .0$. Chairman: T. Urbanek.

2014.11.29, Poznań (Poland) $-29^{\text {th }}$ PTF Conference $/ 1^{\text {st }}$ Aesthetic Phlebology.

2014.12.05-06, Kraków (Poland) $-30^{\text {th }}$ Conference $\mathrm{PTF} / 3^{\text {rd }}$ International Symposium on Venous Interventions. Focus on Acute and Chronic Deep Vein Obstruction (part II).

2015.06.11-13, Kraków (Poland) $-8^{\text {th }}$ International Congress of the Polish Society of Phlebology. President of the Congress: T. Urbanek.

\footnotetext{
${ }^{10}$ A similar title (fellowship) is given to some phlebologists in Australia and the USA: Fellow of Australian/American College of Phlebology (FACPh).

${ }^{11}$ Professor Tomasz Urbanek is the Chairman of the entire series of the International Symposium on Venous Interventions.

${ }^{12}$ www.uip-phlebology.org/uip2013Boston.

${ }^{13}$ Kalatówki is an ecological glade located in the Bystra Valley in the Western Tatras in the vicinity of the city of Zakopane. In Kalatówki there was the first Polish ski resort and the first ski competitions in Poland took place there in 1910.
} 


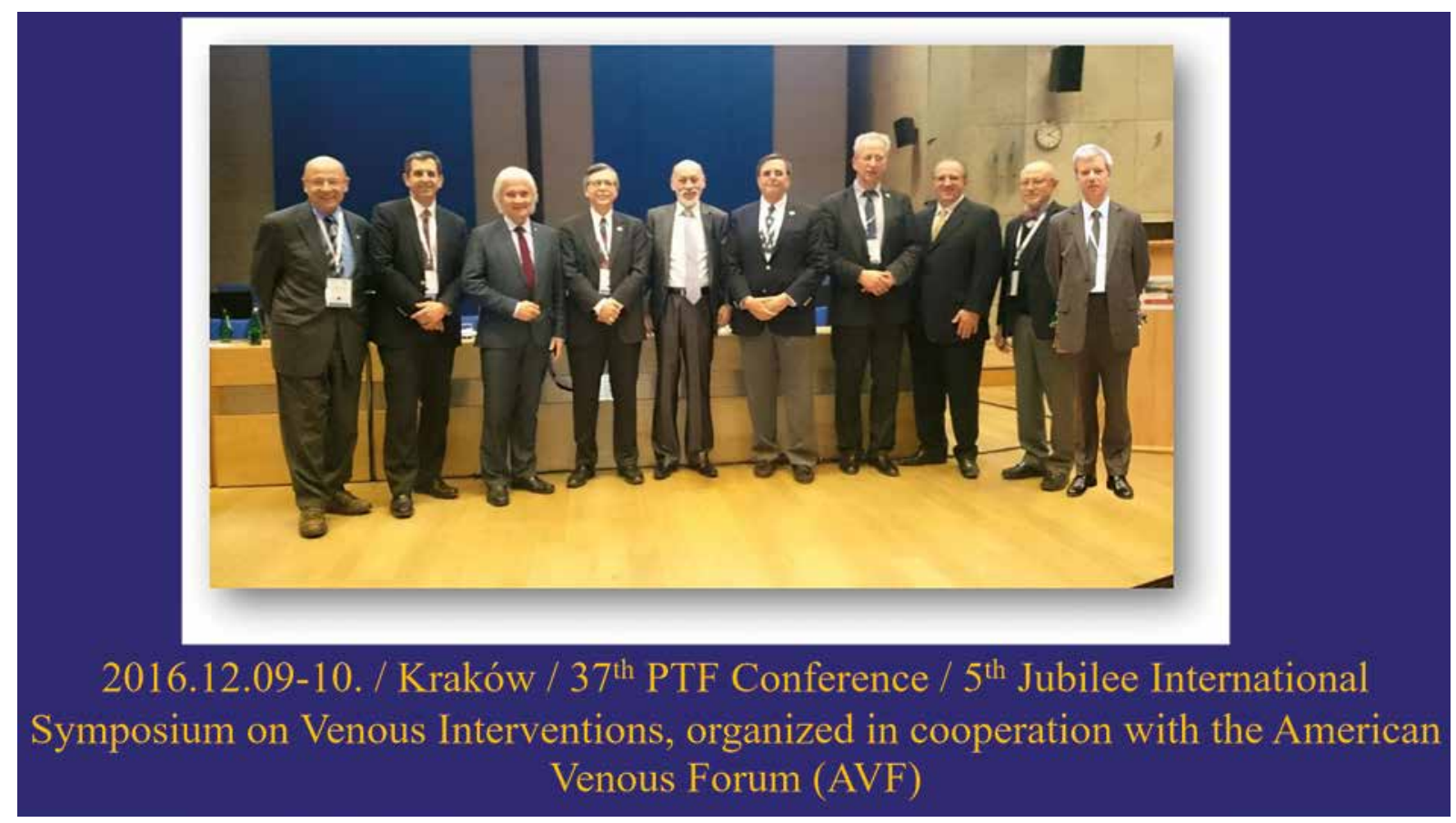

Fig. 6. $37^{\text {th }}$ PTF Conference/ $5^{\text {th }}$ Jubilee International Symposium on Venous Interventions, 09-10.12.2016, Kraków (PL), organized by Polish Society of Phlebology in cooperation with American Venous Forum

2015.06.13 - General Assembly of PTF Members:

Establishment of the Lymphology Section of the PTF. President of the Section: A. Szuba (Wrocław).

Election of the authorities for the $9^{\text {th }}$ term of office 2015-2018.

President - T. Zubilewicz (Lublin), Vice President W. Staszkiewicz, General Secretary - M. Kucharzewski, Treasurer - W. Hendiger, Board Members: M. Gabriel, A. Jawień, G. Madycki, Z. Krasiński, P. Terlecki, Z. Rybak.

One of the invited speakers was professor B.B. Lee ${ }^{14}$ (USA), the world's leading specialist in congenital vascular malformations and lymphedema, and a great friend of Polish phlebologists and vascular surgeons. He has been a frequent guest at our scientific meetings for many years. He has visited the John Paul II Hospital in Kraków twice: in 2007 and 2015. Recently, when watching an operating theatre with a new hybrid room he said, smiling broadly, "I have seen so many vascular centres in the world. I can say that yours is one of the most modern".

2015.09.19, Warszawa (Poland) - $31^{\text {st }}$ PTF Conference $/ 2$ nd Aesthetic Phlebology.

2015.10.22-24, Kraków (Poland) - $6^{\text {th }}$ EVF HOW PLUS Hands-on Workshop on Venous Disease. Directors: B. Eklöf (S/USA), P. Neglén (S/CY), A. Nicolaides (CY/UK). Chairman: T. Urbanek (details ${ }^{15}$.

\footnotetext{
${ }^{14}$ Byung-Boong Lee MD, PhD, FACS - a clinical professor at the George Washington University School of Medicine and Health Sciences, Washington, D.C., director of the Center for Lymphedema and Vascular Malformation.

${ }^{15}$ Phlebological Review 2015; 23, 4: 110-113. https://www. termedia.pl/Journal/Phlebological_Review-76.
}

2015.12.11-12, Kraków (Poland) - $32^{\text {nd }} P T F$ Conference/ $4^{\text {th }}$ International Symposium on Venous Interventions (ISVI). Focus on Ulcus Cruris.

2016.03.17-20, Karpacz (Poland) - $33^{\text {rd }}$ PTF Conference. Advances and Innovations in Phlebology. $25^{\text {th }}$ Anniversary of the PTF. Chairman: T. Urbanek, Z. Rybak.

2016.04.23-24, Wrocław (Poland) - 34. PTF Conference $/ 1^{\text {st }}$ PTF Conference of the Lymphology Section. Lymphoedema - Pathophysiology, Diagnostics, Treatment. Chairman: A. Szuba.

2016.06.11, Warszawa (Poland) $-35^{\text {th }}$ PTF Conference/ $3^{\text {rd }}$ Aesthetic Phlebology.

2016.09.09-11, Zakopane (Poland) $-36^{\text {th }}$ PTF Conference/Phlebology on the Kalatówki Glade v.2.0.

2016.12.09-10, Kraków (Poland) $-37^{\text {th }}$ PTF Conference $/ 5^{\text {th }}$ Jubilee International Symposium on Venous Interventions (ISVI), organized by PTF in cooperation with the American Venous Forum (AVF) Focus on Modern Phlebology. Chairmen: T. Urbanek (PL) and L.S. Kabnick (USA). Special Lecturer J.A. Caprini (USA) ${ }^{16}$ (Fig. 6).

2017.03.17-19, Krynica Górska (Poland) $-38^{\text {th }}$ International Scientific and Training Conference of PTF. Phlebology Today and Tomorrow.

2017.09.23, Warszawa (Poland) $-39^{\text {th }}$ PTF Conference/ $4^{\text {th }}$ Aesthetic Phlebology.

2017.10.26-28, Kraków (Poland) $-8^{\text {th }}$ EVF HOW Plus - Hands-on Workshop on Venous Disease. Chairmen: Marianne De Maeseneer (B), T. Urbanek (Poland), S. Black (UK).

\footnotetext{
${ }^{16}$ www.venousinterventions.com.pl/5th-venous/.
} 
2017.12.08-09, Kraków (Poland) $-40^{\text {th }}$ PTF Conference $/ 6^{\text {th }}$ International Symposium on Venous Interventions (ISVI). Focus on Pelvic Congestion Syndrome and Varicose Vein of Pelvic Origin.

2018.02.04-08, Melbourne (Australia) $-18^{\text {th }}$ World Meeting of the International Union of Phlebology. This again under the auspices of the UIP Congress gathered as usual participants from all over the world including a large group from Poland, who often share with us the knowledge they have acquired. Both the present president of the PTF, T. Urbanek, and his predecessors are already very well recognized in the world and thanks to their experience and commitment they occupy important functions in the international vascular forums, including phlebology. Thanks to this, the rank of our society is constantly growing.

2018.03.16-17, Wrockaw (Poland) $-41^{\text {st }}$ PTF Conference. $2^{\text {nd }}$ Conference of the Lymphology Section of the PTF. Lymphoedema in Oncology.

2018.06.21-23, Lublin (Poland) $-9^{\text {th }}$ International Congress of the Polish Society of Phlebology. President of the Congress: T. Zubilewicz.

2018.06.23 - General Assembly of PTF Members. Election of the authorities for the $10^{\text {th }}$ term of office 2018-2021.

President - T. Urbanek (Katowice), Vice President - M. Gabriel, General Secretary - M. Kucharzewski, Treasurer - W. Hendiger. Board Members: Past-President - T. Zubilewicz, President-Elect for the $11^{\text {th }}$ term of office (2021-2024) - Z. Krasiński, A. Jawień, Z. Rybak, M. Iłżecki, P. Terlecki, A. Jaworucka-Kaczorowska, A. Zieliński.

As a result of close long-term cooperation of Prof. Gloviczki (USA) with Polish phlebologists and vascular surgeons, an interesting idea arose during the congress. Due to the significant advances in phlebology over the past 10 years it has been confirmed to publish in Polish the latest American Handbook of Venous and Lymphatic Disorders - the fourth edition from 2019 edited by Prof. P. Gloviczki (first published in 1996). The scientific editors of the Polish edition (2020), titled Choroby żył i naczyń limfatycznych, are Prof. P. Andziak (Warsaw) and Prof. T. Zubilewicz (Lublin).

2018.09.07-09, Zakopane (Poland) $-42^{\text {nd }}$ PTF Conference/Phlebology on the Kalatówki Glade/v.3.0. Exchange of Experience and Ongoing Discussions of Clinical Phlebological Cases (Fig. 10).

2018.10.06, Warszawa (Poland) $-43^{\text {rd }}$ PTF Conference $/ 5^{\text {th }}$ Jubilee Conference - Aesthetic Phlebology.

2018.11.30-12.01, Kraków (Poland) $-44^{\text {th }}$ PTF Conference $/ 7^{\text {th }}$ International Symposium on Venous Interventions. Focus on Post-Thrombotic Syndrome.

2019.08.25-27, Kraków (Poland) - International Union of Phlebology. UIP Chapter Meeting. Head of Local Organising Committee: T. Urbanek (Poland). The sunny city of Kraków, Poland was an ideal venue for the UIP chapter meeting for 2019. More than 1300 delegates from 71 countries ( 5 continents) attended the meeting over 3 days. Over the course of the 3 days, the scientific programme comprised 4 parallel streams, 36 scientific sessions, 7 poster session and 19 workshops.

Delegates from all over the world participated in this event, enjoying the beauty of Kraków and the latest advances in the industry. The opening ceremony was a visual delight for all those who attended and the gala dinner in the spectacular Gardens of the Archaeological Museum of Kraków.

It was the largest meeting of this type in our part of Europe, highly rated, one of the last international and national direct scientific meetings before the current pandemic $^{17}$.

A nice, pro-ecological event took place during the congress. A symbolic tree was planted to celebrate this event - it was named the UIP 2019 Tree (Fig. 7).

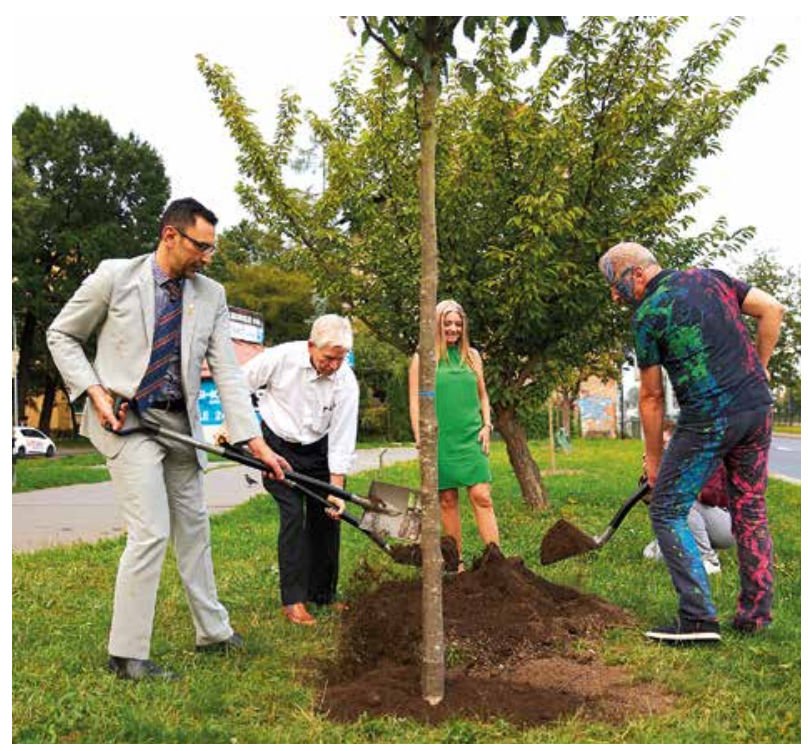

Fig. 7. Union Internationale de Phlébologie Chapter Meeting UIP 2019 Tree (Swedish Whitebeam/Sorbus intermedia), 2019, Kraków (PL)

2019.11.17-18, Warszawa (Poland) $-45^{\text {th }}$ PTF Conference $/ 6^{\text {th }}$ Conference - Aesthetic Phlebology. Aesthetic and minimally invasive treatment in phlebology. Lipoedema - how to proceed? The last direct phlebological meeting in Poland before the pandemic.

2020.11.07-08, Katowice (Poland) $-46^{\text {th }}$ PTF Conference. PTF General Assembly of Members (online). $7^{\text {th }}$ Conference - Aesthetic Phlebology. Phlebology in Poland A.D. 2020.

\footnotetext{
${ }^{17}$ Past World Congress of the Union Internationale de Phlébologie (uip-phlebology.org).
} 


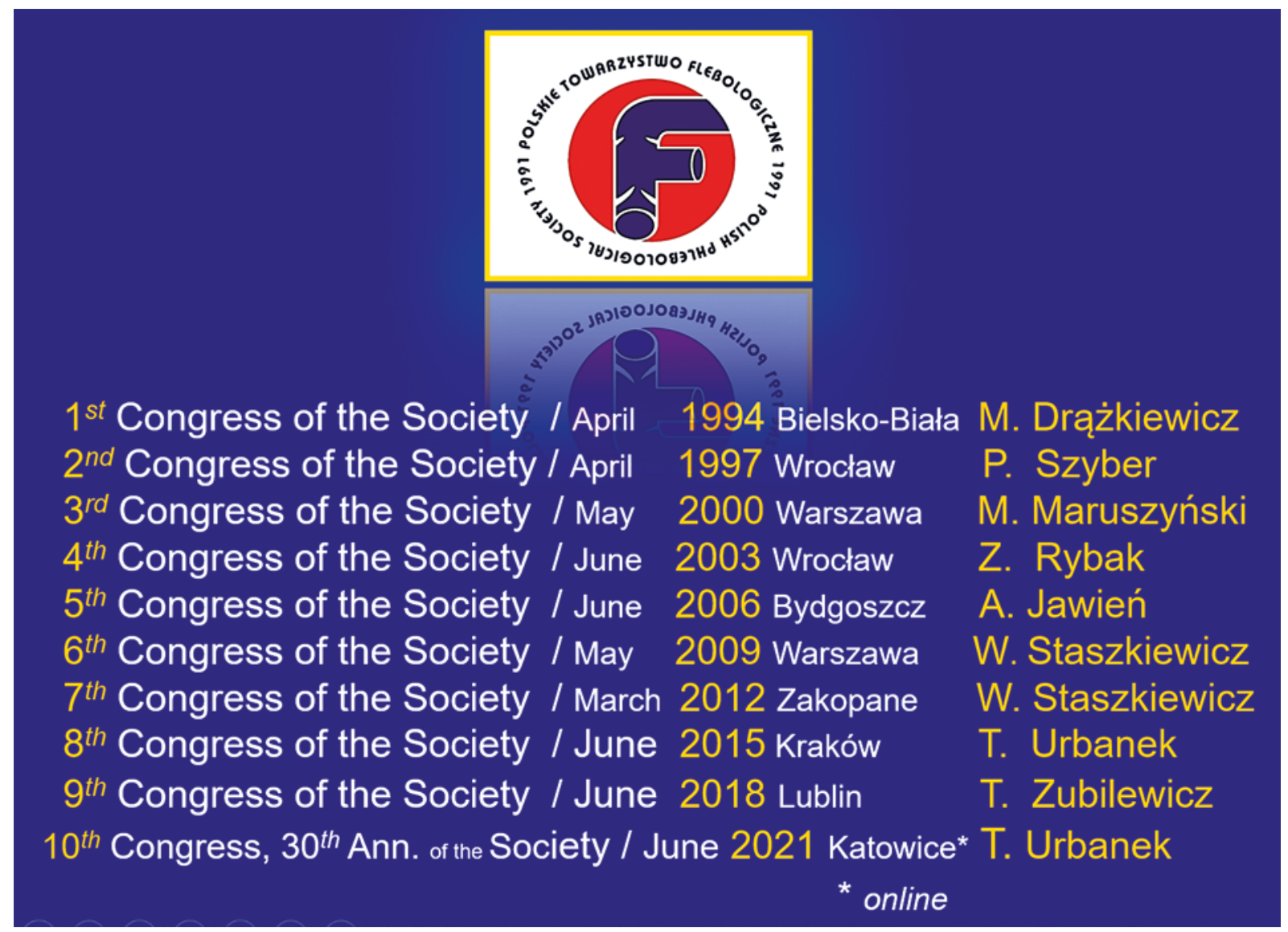

Fig. 8. Congresses of the Polish Society of Phlebology from the $1^{\text {st }}(1994)$ to the $10^{\text {th }}(2021)$

2020.12.12-13, Katowice (Poland) $-47^{\text {th }}$ PTF Conference $/ 8^{\text {th }}$ International Symposium on Venous Interventions. Focus on chronic venous insufficiency (online).

2021.01.28, Katowice (Poland) $-48^{\text {th }}$ PTF Conference. Practical Phlebology, $1^{\text {st }}$ webinar ${ }^{18}$. Treatment of Recurrent Varicose Veins (online).

2021.02.18, Katowice (Poland) $-49^{\text {th }}$ PTF Conference. Practical Phlebology, $2^{\text {nd }}$ webinar. Complications in Phlebology (online).

2021.03.17-20, San Antonio (USA) - $33^{\text {rd }}$ Annual Meeting of the American Venous Forum (AVF), inter alia with active participation (online meeting of the PTF representatives).

2021.03.18, Katowice (Poland) $-50^{\text {th }}$ PTF Conference. Practical Phlebology, $3^{\text {rd }}$ webinar. Treatment of Venous Spider Veins and Pathologies of Reticular Veins in Patients with Chronic Venous Disease - Methods, Difficulties, Results (online).

2021.04.08, Katowice (Poland) - $51^{\text {st }}$ PTF Conference. Practical Phlebology, $4^{\text {th }}$ webinar. Difficulties in surgical treatment of superficial vein insufficiency (online).

2021.04.16-17, Wroclaw (Poland) $-52^{\text {nd }}$ International PTF Conference/I3 ${ }^{\text {rd }}$ International Conference of the ${ }^{18}$ Chairman of the webinar conferences (1-4), Prof. T. Urbanek
(Katowice) MD, PhD, FPSPh.
Lymphology Section of the PTF. LYMPHOEDEMA 2021. Diagnostics, Prevention and Treatment of Lymphatic System Diseases (online). Chairman: A. Szuba.

2021.06.10-12, Katowice (Poland) $-10^{\text {th }}$ Jubilee International Congress and $30^{\text {th }}$ Anniversary of the Polish Society of Phlebology (online) ${ }^{19}$. President of the Congress: T. Urbanek. The current president of the PTF 2018-2021, Prof. Tomasz Urbanek MD, PhD, FPSPh, is now for the second time in this position. He has been very well recognized in the world for many years. Thanks to his experience and commitment, he occupies important functions in the international phlebology forum, and the current level of phlebology in Poland does not deviate from the highest European and world standards. Thanks to him and his predecessors and successor, the rank of our society is constantly growing (Fig. 8, 9).

On $9^{\text {th }}$ of June a General Assembly of Members (online) will be held. Elections will select (online) new PTF authorities for the next $11^{\text {th }}$ term of the PTF Management Board 2021-2024. According to the statute, the position of the president for 2021-2024 should be taken by Prof. Zbigniew Krasiński from Poznań, elected in

${ }^{19}$ For obvious safety reasons, the organization of the congress was adopted only in the form of a virtual meeting (online). 


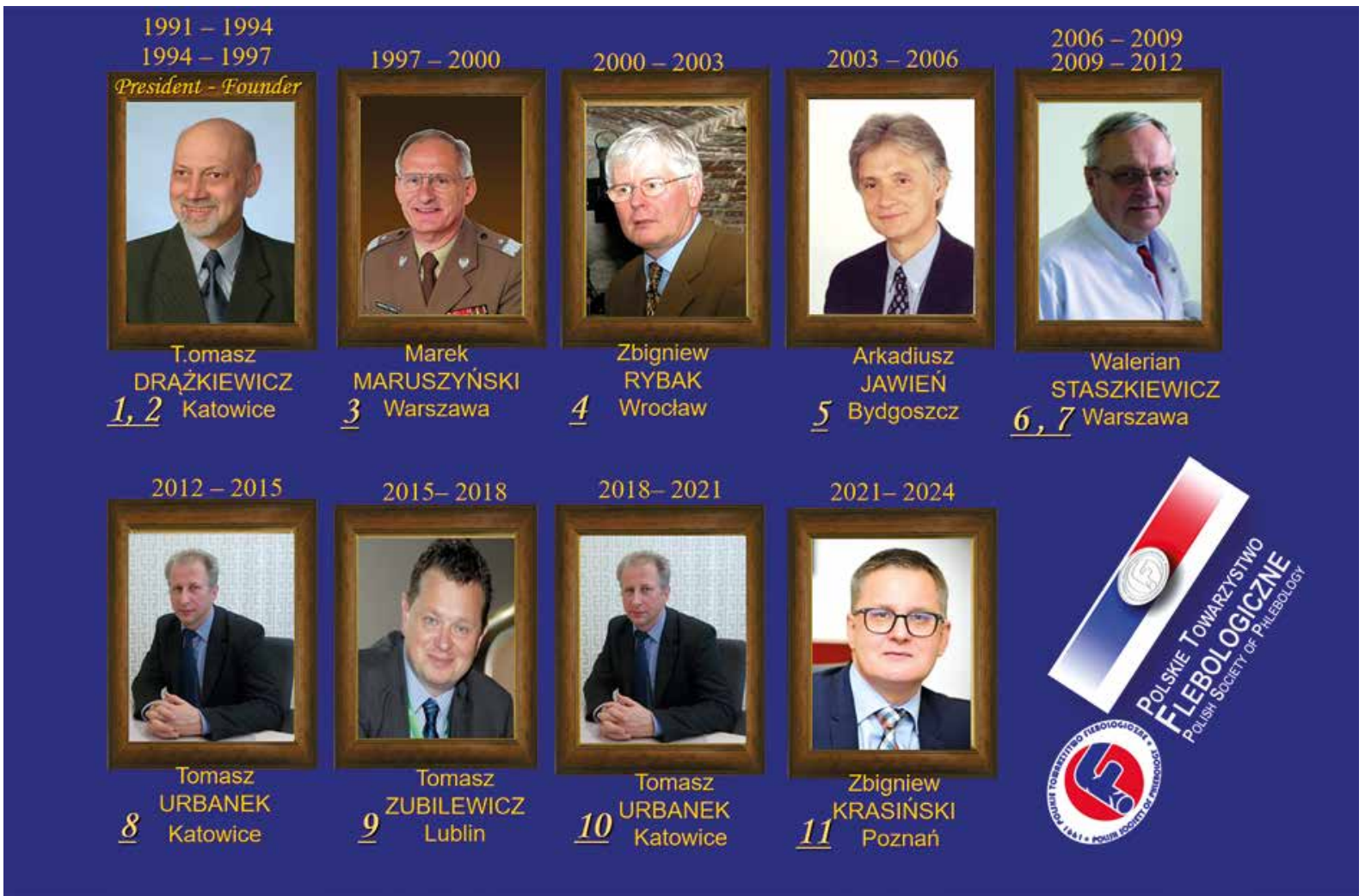

Fig. 9. Presidents of the Polish Society of Phlebology from the $1^{\text {st }}(1991-1997)$ to the $11^{\text {th }}(2021-2024)$

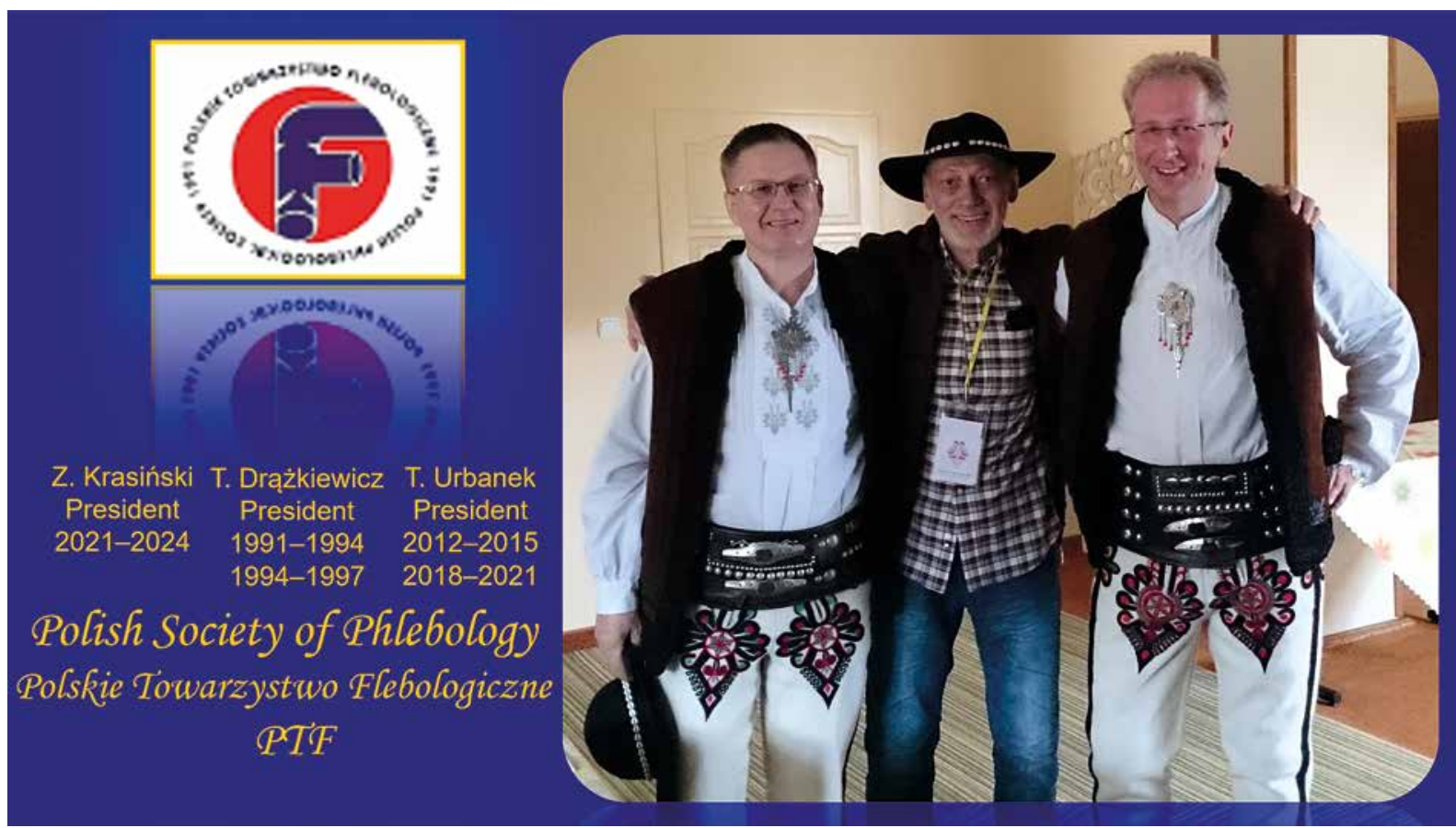

Fig. 10. Polish Society of Phlebology - three presidents at the conference in the Tatra Mountains. In the middle T. Drążkiewicz - the first-founder, on the right T. Urbanek - the present, on the left Z. Krasiński - the next one

Lublin (2018). This congress is another milestone opening a new chapter in Polish phlebology (Fig. 10).

Let's hope that the strength of our society will finally mobilize the Polish government authorities, the Ministry of
Health and Social Welfare (MZiOS) and the National Health Fund (NFZ) to treat patients with chronic venous diseases more seriously, to provide them with reimbursed treatment, which, unfortunately, they often do not have today. 


\section{APPENDIX}

The turn of the $2^{\text {nd }}$ and $3^{\text {rd }}$ decades of the $21^{\text {st }}$ century surprised the whole world with one of the most dangerous phenomena in the history of mankind - a pandemic with unpredictable consequences. Despite this, we phlebologists every day make every effort to work even more intensively in these difficult, dangerous living and working conditions, without sparing our strength.

Over the years I have met hundreds of fascinating people, professional phlebologists. And it continues today. Unfortunately, we have no influence on one thing. Time flies inexorably fast. On the other hand, fortunately, if someone does something useful and leaves a lasting trace for posterity, then that person should be satisfied and happy. I can assure you that I am.

Now - 30 years after the establishment of the Polish Society of Phlebology - the first completely Polish, comprehensive, and ground-breaking work of outstanding Polish phlebologists, Textbook of Phlebology, is published. A modern handbook, devoted to the multidisciplinary field of medicine that is phlebology, has appeared just in time. I am convinced that in such a difficult and special time it will help to fight more effectively for the health and life of our community. At this point, I express my special appreciation to all the people who made this handbook possible.

I would like to provide readers with a lot more information about the history of phlebology. Therefore, I encourage all people with phlebological experience to collect their own interesting memories and find documents or photos that could be used in the future to enrich the history of Polish phlebology and publish it in the form of an extended monograph.

I know that my article does not exhaust the topic of the title. I have known and still know many wonderful people from medical circles, both in Poland and worldwide, who we can call phlebologists. Many have put a lot of time and effort into the development of this multidisciplinary field of medicine. It is impossible to list them all, so I have mentioned only some of them. However, I hope that the current and future authorities will set new milestones in the history of phlebology, which we do not know, because it is still ahead of us. And it should not be anything like science fiction, Back to the Future.

\section{Tomasz Drążkiewicz}

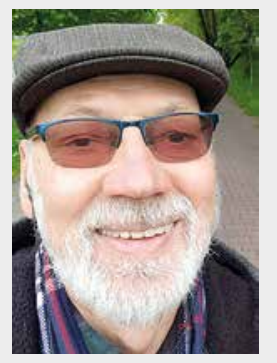

First, second and last names: Tomasz Melchior Drążkiewicz (born October 16, 1949 in Sosnowiec, Poland). He graduated from medical studies at the Medical University of Silesia in Katowice, Poland (formerly the Silesian Medical Academy) 1974. Retired (2015), still an active doctor, general and vascular surgeon, angiologist, phlebologist. $\mathrm{MD}, \mathrm{PhD}, \mathrm{FPSPh} / \mathrm{inter}$ alia: Founder (1991), President (1991-1994 and 1994-1997) and President of Honor (2009) of the Polish Society for Phlebology (Polskie Towarzystwo Flebologiczne - PTF), Founder (1993), Editor-in-Chief (1993-2001) and Editor-in-Chief of Honour (2001) of the Phlebological Review (est. 1993). Honorary Member (1993) of the International Forum for Minisurgery of Varicose Veins (IFMVV). Corresponding Member of the German Society of Phlebology (DGP) and Corresponding Member of the French Society of Phlebology (SFP). Member of the Scientific Advisory Committee of the IUP/UIP (1994-2001).

Tomasz Drążkiewicz recently asked himself how he was doing. Without thinking, he answered, also to himself:

I feel fantastic, because professionally and privately I feel fulfilled.

Professionally, because: the Polish Society of Phlebology has been alive for 30 years and is doing well, the history of the society is written, so I consider it all as my life's work.

And privately? I have a successful family life, an understanding and caring wife, two wonderful and wise daughters, and now I am the happiest because on April 7, 2021 I became for the first time the grandfather of little Maja. That is why I believe that, apart from health and happiness, I do not need anything more. Well, unless I become a grandfather once again.

And what about a hobby? My hobby? I have the least time for that. But when I have the time, I play and compose (keyboard and guitar) and I take photos everywhere.

$$
\text { TOMan DRAZZHELISicz }
$$

